\title{
NECATOR PAUPERUM I NECATOR EGENTIUM W PRAWODAWSTWIE SYNODÓW GALIJSKICH V-VII WIEKU
}

Celem niniejszego artykułu jest analiza użycia wyrażenia necator pauperum (zabójca ubogich), oraz pokrewnego mu necator egentium (zabójca potrzebujących) w prawodawstwie synodów galijskich V-VII wieku1. Cezury czasowe obejmują okres od początku działalności synodalnej w Galii, której dokumentacja się zachowała, do końca VII w., kiedy wraz z dojściem do władzy majordomów w państwie Merowingów ${ }^{2}$ następuje rozpad zorganizowanego życia kościelnego, a działalność synodalna ustaje ${ }^{3}$. Sama idea necator pauperum (i pokrewnego mu necator egentium/aegentium) w dużym uogólnieniu odnosi się do działań przeciw dobrom kościelnym. Jest ona charakterystyczna dla synodów tego okresu i regionu, i zasługuje na szczegółową analizę . Pod-

* Dr Tomasz Skibiński SAC - asystent w Katedrze Historii Starożytnej na Wydziale Nauk Historycznych i Społecznych Uniwersytetu Kard. Stefana Wyszyńskiego w Warszawie; e-mail: t.skibinski@uksw.edu.pl.

${ }^{1}$ Teksty synodalne zostały wydane w: Concilia Galliae a. 314 - a. 506, ed. C. Munier, CCL 148, Turnholti 1963; Concilia Galliae a. 511 - a. 695, ed. C. de Clercq, CCL 148A, Turnholti 1963. Część tych tekstów wraz z tłumaczeniem francuskim ukazała się w serii Sources Chrétiennes: Conciles Gaulois du IV siècle, ed. J. Gaudemet, SCh 241, Paris 1977 (synody IV w.); Les canons des conciles Mérovingiens (VI ${ }^{-}-V I I^{e}$ siècles), t. 1-2, ed. J. Gaudemet - B. Basdevant, SCh 353-354, Paris 1989. $\mathrm{W}$ języku polskim są dostępne następujące wydania, zawierające tekst oryginalny wraz z polskim thumaczeniem: Dokumenty synodów od 50 do 381 roku, red. A. Baron - H. Pietras, SCL 1, Kraków 2006; Dokumenty synodów od 381 do 431 roku, red. A. Baron - H. Pietras, SCL 4, Kraków 2010; Dokumenty synodów od 431 do 504 roku, red. A. Baron - H. Pietras, SCL 6, Kraków 2011; Dokumenty synodów od 506 do 553 roku, red. A. Baron - H. Pietras, SCL 8, Kraków 2014.

${ }^{2} \mathrm{Na}$ temat historii królestw merowińskich zob. I. Wood, Królestwa Merowingów 450-751. Władza - społeczeństwo - kultura, tłum. M. Wilk, Warszawa 2012, oraz w szerszym zakresie czasowym i tematycznym G. Faber, Merowingowie i Karolingowie, thum. Z. Jaworski, Warszawa 1994.

${ }^{3}$ Por. M.D. Knowles - D. Obolensky, Historia Kościoła, t. 2, 600-1500, thum. R. Turzyński, Warszawa 1988, 29. Na temat synodów merowińskich zob. O. Pontal, Histoire des conciles mérovingiens, Paris 1989.

${ }^{4}$ Kilka przykładów użycia tego terminu w kontekście zabiegów o zachowanie majątków kościelnych zostało omówionych w: B.H. Rosenwein, Negotiating Space: Power, Restraint, and Privileges of Immunity in Early Medieval Europe, Ithaca (NY) 1991, 42-47. Krótki, ale niekompletny i pozostawiony bez dalszej analizy wykaz tekstów synodów galijskich wykorzystujących analizowane wyrażenie przytacza także M.E. Moore, The Ancient Fathers: Christian Antiquity, Patristics and 
jęte zagadnienie zostanie ukazane w dwóch zasadniczych zakresach: pierwszy dotyczy zatrzymania obiecanych ofiar lub odbierania darów już złożonych, drugi zaś - zawłaszczania dóbr kościelnych.

1. Zatrzymanie lub odbieranie zlożonych ofiar. Analizowane wyrażenie występuje bardzo często w kontekście zwłoki lub odmowy przekazania Kościołowi ofiar złożonych lub zapisanych testamentem przez zmarłych oraz odbierania tych, które już zostały przekazane.

Po raz pierwszy pojawia się w poł. V w. na synodzie w Vaison (442):

„Zatrzymujący ofiary zmarłych i zwlekający z przekazaniem ich Kościołowi, mają być usunięci z Kościoła jako niewierzący, ponieważ pewne jest, że dochodzi aż do poniżenia wiary i prowokowania Bożej łaskawości. W ten sposób oszukuje się umierających wiernych, jeśli idzie o pełnię ich wotów, a biednych pozbawia środków na życie i niezbędne utrzymanie. Takich trzeba uważać jakby za zabójców [ludzi] potrzebujących i za niewierzących w sąd Boży; stąd jeden z Ojców zamieścił w swoim piśmie podobne zdanie, w którym mówi: Zabrać coś przyjacielowi jest kradzieża, oszukać Kościół - świętokradztwem”.

Powyższy kanon jest jednym z bardziej rozbudowach wśród tekstów synodalnych dotyczących analizowanego wyrażenia. Możemy w nim wyróżnić trzy zasadnicze części. Przede wszystkim jest zdefiniowana wina, polegająca na zatrzymywaniu ofiar zmarłych i zwłoce w przekazaniu ich Kościołowi, za co jest przewidziana bardzo poważna kara usunięcia winnego z Kościoła. Jest to bowiem - jak uzasadnia synod - ,poniżenie wiary i prowokowanie Bożej łaskawości”, ponieważ oszukuje się zmarłych co do ich wotów. Druga część kanonu odnosi się już do analizowanego przez nas wyrażenia i je uzasadnia. Stwierdza, że powyższe przestępstwo pozbawia biednych środków, które mają być przeznaczone na ich życie i utrzymanie, dlatego winnych należy traktować jako zabójców ludzi potrzebujących (egentium necatores), a zarazem niewierzących w sąd Boży ${ }^{6}$. W ostatniej części tekstu synod dodatkowo uzasadnia

Frankish Canon Law, „Millennium, Jahrbuch zu Kultur und Geschichte des ersten Jahrtausends n. Chr.” 7 (2010) 320-323. O analizowanym wyrażeniu w kontekście troski o zapewnienie środków na działalność charytatywną Kościoła zob. T. Skibiński, Dzieło charytatywne Kościoła w Galii w IV-VII wieku w świetle prawodawstwa synodalnego. Zarys problematyki, VoxP 35 (2015) t. 64, 382.

${ }^{5}$ Concilium Vasense (442), can. 4, SCL 6, 22: „Qui oblationes defunctorum fidelium detinent et ecclesiae tradere demorantur, ut infideles sunt ab ecclesia abiiciendi, quia usque ad exinanitionem fidei peruenire certum est hanc pietatis diuinae exacerbationem, qua et fideles de corpore recedentes uotorum suorum plenitudine et pauperes collatu alimoniae et necessaria sustentatione fraudantur. Tales enim quasi egentium necatores nec credentes iudicium Dei habendi sunt unius quoque patrum in hoc, quam scriptis suis inseruit, congruente sententia qua ait: amico quidpiam rapere furtum est, ecclesiam fraudare sacrilegium", tłum. A. Caba, SCL 6, 22*.

${ }^{6}$ Synod - jak widzimy - traktuje tu jako synonimy dwa pojęcia: „,biedni” oraz „,potrzebujący”. Jak zobaczymy w toku dalszych analiz, także w innych tekstach synodalnych będą one pojawiać się zamiennie. 
powyższe stwierdzenia powołując się na cytat z listu Hieronima do Nepocjana o kwalifikacji kradzieży rzeczy należących do przyjaciela oraz Kościoła, który uznał pierwsze za kradzież, drugie zaś za świętokradztwo?

Ustalenia powyższego kanonu są wielokrotnie przywoływane w późniejszych dokumentach. Statuta Ecclesiae Antiqua ${ }^{8}$ używają tego samego określenia necator egentium i odnoszą je, podobnie jak synod w Vaison, do osób odmawiających Kościołowi ofiar osób zmarłych ${ }^{9}$ lub oddających je z trudnością. Zbiór przewiduje też podobną karę: winni, jako zabójcy potrzebujących, mają być ekskomunikowani ${ }^{10}$.

Idea ponownie pojawia się w kanonie wizygockiego synodu w Adge z roku 506, który stanowi:

„Duchowni lub świeccy, którzy postanowiliby zatrzymać dla siebie ofiary rodziców, złożone albo pozostawione w testamentach, czy też uznaliby, że należy odebrać to, co oni sami dali kościołom lub klasztorom, to tak jak postanowił święty synod, jakby zabójcy biednych, powinni zostać wykluczeni z kościołów, dopóki wszystkiego nie oddadzą" ${ }^{11}$.

W tekście - jak łatwo zauważyć - zamiast stosowanego wcześniej necator egentium, jest użyte nowe określenie, necator pauperum, które będzie dużo częstsze od poprzedniego. Tekst powtarza wcześniejsze ustalenia dotyczące zatrzymania ofiar zmarłych, ale pojawiają się w nim także nowe elementy. Najpierw synod poszerza dotychczasowe ustalenia, dodając doprecyzowanie:

\footnotetext{
${ }^{7}$ Por. Hieronymus, Epistula 52, 16, ed. I. Hilberg, CSEL 54, Vindobonae - Lipsiae 1910, 439.

${ }^{8}$ Jest to zbiór kanonów Kościoła sporządzony prawdopodobnie przez Gennadiusza z Marsylii w latach 476-486, por. Ch. Munier, Statuta Ecclesiae Antiqua, NDPAC III 5113; więcej na temat zbioru zob. tamże, 5113-5115).

${ }^{9}$ Polskie wydanie zbioru thumaczy „Qui oblationes defunctorum aut negant ecclesiis aut cum difficultate reddunt”, jako „Ci, którzy ofiar za zmarłych odmawiają kościołom lub z trudem je oddają" (Statuta Ecclesiae Antiqua 86 (95), SCL 6, 269, thum. A. Caba, SCL 6, 269*). Wydaje się jednak, że prawodawca ma na myśli raczej ofiary, które zmarły przed śmiercią polecił przekazać Kościołowi, tak więc winny nie jest tutaj ofiarodawca, ale tylko przekazicielem ofiary złożonej przez kogoś innego, w związku z czym trafniejszym thumaczeniem jest „Ci, którzy ofiar zmarłych odmawiają kościołom lub z trudem je oddają”, analogicznie do ustaleń cytowanego wyżej kanonu synodu w Vaison.

${ }^{10}$ Por. tamże: „Qui oblationes defunctorum aut negant ecclesiis aut cum difficultate reddunt, tanquam egentium necatores excommunicentur".

${ }^{11}$ Concilium Agathense (506), can. 4, SCL 8, 2: „Clerici etiam uel saeculares, qui oblationes parentum aut donatas aut testamentis relictas retinere perstiterint, aut id quod ipsi donauerint ecclesiis uel monasteriis crediderint auferendum, sicut synodus sancta constituit, uelut necatores pauperum, quousque reddant, ab ecclesiis excludantur", thum. B. Tabor, SCL 8, 2* ze zmianą. Powyższe polskie tłumaczenie w pierwszej części brzmi: „Duchowni lub świeccy, którzy postanowiliby zatrzymać dla siebie złożone ofiary za rodziców, albo pozostawione w testamentach", jednak podobnie jak w wypadku wyżej cytowanego tekstu Statuta Ecclesiae Antiqua trafniejsze wydaje się thumaczenie „Duchowni lub świeccy, którzy postanowiliby zatrzymać dla siebie ofiary rodziców, złożone albo pozostawione w testamentach”.
} 
chodzi o ofiary rodziców i to zarówno już złożone (i prawdopodobnie przekazane dzieciom celem dalszego ich przekazania Kościołowi), jak i zapisane testamentem. Następnie, pojawia się nowy element, gdy synod określa, że odnosi się także do prób odebrania ofiar już wcześniej przekazanych kościołom lub klasztorom ${ }^{12}$. Także ci winni, jako zabójcy biednych mają być wykluczeni z kościołów (ab ecclesiis excludantur), dopóki wszystkiego nie oddadzą. Przez ten ostatni element, określenie czasu wykluczenia winnego z Kościoła i danie mu szansy poprawy, sankcja synodu nabiera charakteru kary naprawczej.

$\mathrm{W}$ prawodawstwie synodów merowińskich wyrażenie necator pauperum pojawia się po raz pierwszy w roku 549 na synodzie w Orleanie ${ }^{13}$. Aż trzy kanony tego synodu używają tego określenia odnosząc je do różnych przestępstw, lecz zatrzymywanie ofiar wiernych traktując tylko marginalnie, a skupiają się zasadniczo na atakach na dobra kościelne, co zostanie przeanalizowane w drugiej części artykułu. W tym miejscu warto zwrócić tylko uwagę, że nawiązując do regulacji zawartych w przytoczonym już wyżej kanonie 4. synodu w Adge ${ }^{14}$, w kanonie 13. synod zakazuje m.in. zatrzymywania dóbr i majątku przekazanych prawnie instytucjom kościelnym w celach dobroczynnych, a winny złamania zakazu jako zabójca ubogich (necator pauperum) ma być wykluczony z progów kościoła do czasu naprawienia szkód ${ }^{15}$. Z kolei kanon 16. piętnuje zabieranie datków ofiarowanych przez rodziców „kapłanom, kościołom czy jakimkolwiek świętym miejscom w celu uzyskania zasługi ku chwale Boga"16. Winny - jako zabójca ubogich (necator pauperum) - ma być pozbawiony komunii.

Zabójcy potrzebujących są piętnowani także na synodzie w Mâcon(581-583):

„Aby ci, którzy zatrzymują ofiary wiernych zmarłych, które zostały złożone kościołom, jako zatrzymujący cudzą własność i zabójcy potrzebujących, byli usunięci z dala od progów Kościoła" ${ }^{17}$.

${ }^{12}$ To przestępstwo, będące już atakiem na dobra kościelne, zostanie szerzej omówione w drugiej części artykułu.

${ }^{13}$ Warto zwrócić uwagę, że także na tym synodzie analizowana idea jest wyrażona w formie necator pauperum, zamiast wcześniejszego necator egentium.

${ }^{14} \mathrm{Na}$ zależność kanonu 13. od regulacji synodu w Agde zwróciła uwagę B.H. Rosenwein (Negotiating Space, s. 42).

${ }^{15}$ Por. Concilium Aurelianense (549), can. 13, SCL 8, 319: „Ne cui liceat res uel facultates ecclesiis aut monasteriis uel exenodociis pro quacumque elemosina cum iustitia deligatas retentare, alienare adque subtrahere. Quod quisque fecerit, tanquam necator pauperum antiquorum canonum sententiis constrictus ab ecclesiae liminibus excludatur, quamdiu ab ipso ea, quae sunt ablata uel retenta, reddantur", tłum. P. Wałach, SCL 8, 319*. Warto zauważyć, że Synod zaznacza tutaj, iż jest to regulacja zawarta $\mathrm{w}$, dawnych kanonach".

${ }^{16}$ Tamże, can. 16, SCL 8, 320-320*: „Quisquis etiam aut maiorum aut mediocrium personarum quodcumque muneris uel facultatis sacerdotibus aut eclesiis aut quibuslibet locis sanctis studio mercedis cum iustitia pro Dei contemplatione contulerit aut ea, quae a parentibus donata noscuntur, postmodum auferre praesumserit, superiori sententia ut necator pauperum a communione priuabitur".

${ }^{17}$ Concilium Matisconense (585), can. 4, CCL 148A, 224: „Vt, qui oblationes fidelium defun- 
Jak widzimy, ten synod ponownie bierze pod uwagę ogólnie ofiary zmarłych (a nie tylko rodziców). Powtarzając też ideę obecną w poprzednich ustaleniach synod odnosi do winnych zatrzymania ofiar zmarłych znane nam już określenie zabójców potrzebujących (aegentium necatores), ale dodaje nowe - „zatrzymującego cudzą własność” (retentator). Nie określa też warunków cofnięcia kary.

Po raz ostatni w okresie merowińskim wstrzymanie ofiar należnych kościołowi zostanie potępione w kanonie 12. synodu w Clichy (626-627), który powtarza dosłownie przytoczoną wyżej regulację zawartą w kanonie 4. synodu w Adge z 506 roku $^{18}$.

2. Zabór dóbr kościelnych. Drugim motywem nadania miana zabójcy ubogich (necator pauperum) w synodach galijskich jest zabór dóbr kościelnych przez różnego rodzaju ataki. Dobra te powiększają się szczególnie w państwie Franków w związku ze sprzyjająca polityką oraz licznymi darowiznami, w tym pochodzącymi od samego króla. O takich darowiznach królewskich wspomina już pierwszy synod merowiński jaki został zwołany przez Chlodwiga i odbył się w Orleanie w roku 511:

„Co do ofiar i pól, które pan nasz król raczył przekazać w darze kościołom albo z Bożego natchnienia przekaże je tym, którzy ich jeszcze nie mają, udzieliwszy zwolnienia co do samych pól i duchownych, orzekamy, że to jest najsprawiedliwsze, żeby w odnawianiu kościołów, utrzymaniu duchownych i ubogich oraz wykupie jeńców, cokolwiek Bóg raczyłby dać w owocach, było to wypłacane, a duchowni byli zobowiązani do wspierania kościelnego dzieła" ${ }^{19}$.

Także kolejne synody będą do takich darowizn nawiązywać. W aktach synodu w Walencji (583-585) biskupi stwierdzają najpierw, że zebrali się pod rządami króla Guntrama (561-592), aby rozważyć różne skargi biednych. Następnie nawiązują do przesłanego na synod przez Asklepiodatusa listu króla, zawierającego instrukcje dotyczące fundacji królowej Austrechildy i jej córek Chlodebergi i Klotyldy ${ }^{20}$, poczynionych na rzecz bazylik św. Marcelego w Chalon-sur-Saône i św. Symfroniana w Autun. Zastanawiając się następnie

ctorum, quae ecclesiis conferuntur, retinent, uelut retentatores aut aegentium necatores ab ecclesiae liminebus arceantur", tłum. własne.

${ }^{18}$ Por. Concilium Clippiacense (626-627), can. 12, CCL 148A, 294.

${ }^{19}$ Concilium Aurelianense (511), can. 5, SCL 8, 25: „De oblationibus uel agris, quos domnus noster rex ecclesiis suo munere conferre dignatus est uel adhuc non habentibus Deo sibi inspirante contulerit, ipsorum agrorum uel clericorum inmunitate concessa, id esse iustissimum definimus, ut in reparationibus ecclesiarum, alimoniis sacerdotum et pauperum uel redemtionibus captiuorum, quidquid deus in fructibus dare dignatus fuerit, expendatur et clereci ad adiutorium ecclesiastici operis constringantur", thum. A. Caba, SCL 8, 25*. Wspomniany tu temat immunitetu dóbr kościelnych okresu Merowingów był szeroko dyskutowany w literaturze; por. G.I. Halfond, Archaeology of Frankish Church Councils, AD 511-768, Leiden - Boston 2010, 128 (tam dalsza literatura).

${ }^{20}$ Genealogię rodu Merowingów zob. w: Wood, Królestwa Merowingów 450-751, s. 363-369. 
jak ochronić w przyszłości te bazyliki i inne miejsca święte, biskupi postanowili, że to, co rodzina królewska ofiarowała tym miejscom, w przyszłości nie może być im odebrane ani pomniejszone przez miejscowego biskupa ani władzę królewską (potestas regia). Winny naruszenia tego postanowienia jako „zabójca ubogich” ma być ukarany wieczystą anatemą ${ }^{21}$.

Kiedy również inne dobra kościelne stają się przedmiotem zaboru, synody podejmują regulacje przeciw winnym, określając ich jako zabójców ubogich w świetle argumentów przedstawionych już wyżej: majątek kościelny ma służyć dziełu charytatywnemu, a więc pomocy ubogim.

Obszernie zajmuje się tym problemem synod w Orleanie w 549 r., który aż w trzech kanonach używa określenia necator pauperum odnosząc je do różnych przestępstw. Kanon 13. stanowi:

„Nikomu nie wolno sprzedać, zatrzymać ani zabrać dóbr i majątku przekazanych prawnie kościołom, klasztorom, hospicjom w celach dobroczynnych. Jeśli ktoś tak uczyni, jako morderca ubogich, powściągnięty w karby mocą dawnych kanonów będzie z dala od progów kościoła, dopóki nie odda tego, co zabrał"22.

Nawiązując do „dawnych kanonów” synod przywołuje tu ideę obecną w przytoczonym wyżej kanonie 4. synodu w Adge ${ }^{23}$. Synod w Orleanie (549) nie uzasadnia już jednak dlaczego winny sprzedaży, zatrzymania albo zaboru dóbr przekazanych instytucjom kościelnym staje się zabójcą ubogich, jak to obszernie uczynił synod w Agde. Biorąc pod uwagę aż trzykrotne użycie tego wyrażenia na synodzie bez dodatkowych motywacji i wyjaśnień, oraz fakt, że - jak zobaczymy - powróci ono już po 4 latach w dokumentach synodu w Arles, można wnioskować, że wyrażenie to stawało się powszechnie znane, a idea, która się w nim kryła - jasna i zrozumiała.

Do tego samego synodu w Agde, choć już bez bezpośredniego odwoływania się, nawiązuje także kanon 16. synodu w Orleanie, który - jako zabójcy ubogich - grozi pozbawieniem komunii temu, kto zabiera dobra ofiarowane z motywów religijnych kapłanom, kościołom lub jakimkolwiek świętym miejscom ${ }^{24}$.

${ }^{21}$ Por. Concilium Valentinum (583-585), Acta w. 25-29, CCL 148A, 235: „Quod si quis hoc quocunque tempore temerare aut auferre praesumpserit, ueluti necator pauperum anathemate perpetuo iudicii diuini plectatur et ueluti sacrilegii perpetrator criminis sui reus supplicii aeterni teneatur obnoxius".

${ }^{22}$ Concilium Aurelianense (549), can. 13, SCL 8, 319-319*: „Ne cui liceat res uel facultates ecclesiis aut monasteriis uel exenodociis pro quacumque elemosina cum iustitia deligatas retentare, alienare adque subtrahere. Quod quisque fecerit, tanquam necator pauperum antiquorum canonum sententiis constrictus ab ecclesiae liminibus excludatur, quamdiu ab ipso ea, quae sunt ablata uel retenta, reddantur".

${ }^{23}$ Por. Rosenwein, Negotiating Space, s. 42.

${ }^{24}$ Por. Concilium Aurelianense (549), can. 16, SCL 8, 320: „Quisquis etiam aut maiorum aut mediocrium personarum quodcumque muneris uel facultatis sacerdotibus aut eclesiis aut quibuslibet locis sanctis studio mercedis cum iustitia pro Dei contemplatione contulerit aut ea, quae a parentibus 
Synod w Paryżu (614) dba także o to, by nikt nie naruszył majątku kościoła albo prywatnej własności duchownych po ich śmierci: aż do czasu zbadania testamentu albo innych poleceń, dobra te mają być zabezpieczone przez archidiakona albo innego członka kleru. Jakiekolwiek naruszenie tej zasady ma skutkować pozbawieniem winowajcy komunii jako „,zabójcy ubogich"25. Z kolei Synod w Chalon (647-653) chroni dobra kościelne przed zajęciem przed ostatecznym wyrokiem sądowym; ponownie też określa, że winny tego przestępstwa ma być uznany za zabójcę ubogich ${ }^{26}$.

Ustalenia synodalne są skierowane nie tylko przeciw agresorom zewnętrznym, bo zaboru dóbr, a tym bardziej ich sprzedaży, mógł dokonać także duchowny odpowiedzialny za administrowanie nimi ${ }^{27}$. Niektóre postanowienia synodalne zabezpieczają też wprost przed nadużyciami i zaborem ze stronny duchowych. Jak zwróciła uwagę Barbara H. Rosenwein, kanon 15. synodu w Tours zabezpiecza hospicjum w Lyonie, ufundowane przez króla Childeberta (496-558, król od 511) i jego żonę Ultrogothę przed zajęciem lub pomniejszaniem jego majątku przez duchownych ${ }^{28}$. Synod stanowi:

„Cokolwiek zostanie przekazane temu hospicjum czy to w formie ofiary wspomnianych władców czy dzięki dobroczynności wiernych, w rzeczach i ludziach, pod żadnym pozorem biskup Lyonu nie może przywłaszczyć tego dla siebie ani dla swego kościoła. Następujący zaś po sobie koleją losu kapłani nie tylko nie uszczkną niczego z majątku hospicjum, ale także zadbają o to, żeby trwałość tej instytucji nie poniosła żadnej straty ani uszczerbku"29.

donata noscuntur, postmodum auferre praesumserit, superiori sententia ut necator pauperum a communione priuabitur".

${ }^{25}$ Por. Concilium Parisiense (614), can. 9 (7), CCL 148A, 277: „His etiam constitutionibus adnecti placuit, ut defuncto episcopo, presbytero uel diacono uel quemquam ex iuniore ordine clericum non per preceptum neque per iudicem neque per qualemcumque personam res ecclesiae uel eorum proprietas, quousque aut de testamentis aut qualemcumque obligationem fecerit cognoscatur, a nullo penitus supra scriptae res contingantur, sed ab archidiacono uel clero in omnibus defendantur et conseruentur. Quod si quis inmemor definitionis huius temere aliquid exinde auferre presumpserit aut auso temerario in res ipsas ingressus fuerit et de dominatione ecclesiae abstulerit, ut negatur pauperum a communione priuetur".

${ }^{26}$ Por. Concilium Cabilonense (647-653), can. 6, CCL 148A, 304: „Vt nullus ante audientia res quarumlibet ecclesiarum inuadere aut auferre praesumat. Quod qui feceret, ut negatur pauperum habeatur".

${ }^{27} \mathrm{O}$ duchownych jako możliwych necatores pauperum/egentium wspominały już przytoczone wyżej teksty: Concilium Agathense (506), can. 4, SCL 8, 2; Concilium Valentinum (583-585), Acta w. 25-29, CCL 148A, 235.

${ }^{28}$ Por. Rosenwein, Negotiating Space, s. 44-45.

${ }^{29}$ Concilium Aurelianense (549), can. 15, SCL 8, 319-319*: „Quidquid praefato exenodocio aut per supra dictorum regum oblationem aut per quorumcumque fidelium elemosinam conlatum aut conferendum est in quibuscumque rebus adque corporibus, nihil exinde ad se quolibet tempore antestis ecclesiae lugdunensis reuocet aut ad ius ecclesiae transferat, ut succedentes sibi per temporum ordinem sacerdotes non solum aut de facultate exenodocii ipsius aut de consuetudine uel 
Każdy, kto działaby przeciwko tej instytucji przez naruszenie jej praw i majątku czy przez jej zamknięcie, jako „morderca ubogich” ma zostać obłożony nieodwołalną anatemą ${ }^{30}$.

Zwołany 5 lat później synod w Arles zabrania duchownym pomniejszania majątków, jakie zostały im powierzone przez biskupa. Synod postanawia także, że jeśliby duchowny złamał postanowienie synodu, to młodszy winien ponieść karę cielesna, natomiast starszego należy uznać za „zabójcę ubogich” (necator pauperum $)^{31}$. Synod nie określa wprost konsekwencji jakie wynikają z uznania duchownego za zabójcę ubogich, co jest kolejnym argumentem za uznaniem za znane i zrozumiałe zarówno samego wyrażenia, jak i wiążących się z nim konsekwencji ${ }^{32}$.

Także synod w Clichy (626-627) orzeka, że biskup, który ośmieli się zająć albo uzurpować czy żądać dóbr należących do innego kościoła bez prawnego rozstrzygnięcia, i przyłączy je do swojej własności albo własności swego kościoła ma być na długi czas pozbawiony komunii jako zabójca ubogich i zdjęty z urzędu ${ }^{33}$.

W niektórych tekstach uznanie winnego za „zabójcę ubogich” nabiera cech formalnych i wymaga określonych procedur, do których należy chociażby obowiązek wcześniejszego upomnienia winnego. W dokumentach synodów w Tours (567) oraz Paryżu (556-573) zachowały się dwa identyczne zapisy $^{34}$ dotyczące zaboru dóbr przekazanych przez wiernych Kościołowi ze względów religijnych. Ponownie jest mowa o tym, że winny ma być pozbawiony komunii i uznany za obcego przez wszystkie Kościoły, aż do czasu naprawienia krzywdy. Synody orzekają też, że winni takiego przestępstwa mają być uznani za zabójców ubogich, ponieważ pozbawiają ich żywności,

institutione nil minuant, sed dent operam, qualiter rei ipsius stabilitas in nullam partem detrimentum aut deminutionem aliquam patiatur".

${ }^{30}$ Ostatnia część kanonu brzmi: „Quod si quis quolibet tempore, cuiuslibet potestatis aut ordinis persona, contra hanc constitutionem nostram uenire timptauerit aut aliquid de consuetudine uel facultate exenodocii ipsius abstulerit, ut exenodotium, quod auertat deus, esse desinat, ut necator pauperum inreuocabili anathemate feriatur" (tamże, SCL 8, 319-320).

${ }^{31}$ Por. Concilium Arelatense (554), can. 6, CCL 148A, 172: „Quod si fecerint si iunior fuent disciplina corrigatur, si uero senior, ut necator pauperum habeatur".

${ }^{32}$ Wydaje się, że w interpretacji tego i innych tak ogólnie skonstruowanych tekstów możemy posłużyć się analogicznymi tekstami, jak chociażby przyjętymi na poprzednim synodzie [Orlean (549)]. Jest to tym bardziej uzasadnione, że synod w Orleanie był niedawny i na pewno znany, gdyż zgromadził najwyższą liczbę uczestników spośród wszystkich synodów galijskich VI w.; por. SCL $8,315^{*}$, nota A.

${ }^{33}$ Por. Concilium Clippiacense (626-627), can. 24, CCL 148A, 296: „Si quis episcopus res, quae ab alia ecclesia presentialiter possidentur, quocumque ingenium aut callida cupiditate peruaserit et sine audientia presumpserit usurpare hac suis uel ecclesiae suae ditionibus reuocare, diu communione priuatus ut negator pauperum, ab officium deponatur".

${ }^{34}$ Nie jest jednoznaczne, który z synodów odbył się pierwszy; por. J. Gaudemet - B. Basdevant, Concile de Paris III, w: SCh 354, 410. 
ale zobowiązują biskupa, by w sposób bezpośredni napomniał winnego zanim zostanie na niego nałożona ta sankcja ${ }^{35}$.

Ten sam synod w Tours (567) pozostawił także instrukcję formalnych, pisemnych napomnień winnych i określił procedurę uznania winnego zaboru dóbr kościelnych za zabójcę ubogich ${ }^{36}$. Rozbudowany kanon 25 . tego synodu stwierdza, że niekiedy biskupi czują się bezsilni wobec poczynań władców świeckich. Odwołując się - jak to już widzieliśmy poprzednio - do wcześniejszych ustaleń (quamquam priorum canonum sit auctoritate prefixum) i nawiązując do walk toczących się w królestwie (dum inter se saeuiunt domni nostri) napomina, by w toku walk nie zostały naruszone dobra należące do Kościoła, duchownych, klasztorów i opatów. Gdyby tak się stało, kapłan odpowiedzialny za zawłaszczone dobra ma agresora pisemnie wezwać do poprawy, dając mu na to potrzebny czas. Po trzykrotnym nieskutecznym napomnieniu synod nakazuje zwołać wszystkich duchownych w celu odprawienia specjalnej i obowiązkowej dla wszystkich ceremonii, w czasie której mają odmówić Psalm 108, aby takiego zabójcę ubogich dotknęły przekleństwa, jakie wcześniej spadły na Judasza, który także napełniał swój trzos okradając ubogich ${ }^{37}$.

Biskupi przyznają, że nie mają innej broni (arma nobis non sunt altera), a wobec winnego tak wielkiego przestępstwa posługują się ekskomuniką i anatemą ${ }^{38}$. Zgodnie z tym samym kanonem ekskomunika grozi także biskupowi, który odmówiłby przybycia na tę ceremonię i nie przysłał zastępcy w osobie opata albo kapłana, jak i temu, kto wbrew dekretowi synodalnemu utrzymywałby jedność z przestępcą ${ }^{39}$.

${ }^{35}$ Por. Concilium Turonense (567), can. 26 (25), CCL 148A, 193 [=Concilium Parisiense (556573)], can. 1, CCL 148A, 205): „Indigne enim ad altare domini properare permittitur, qui res ecclesiasticas et audet rapere et iniuste possedere iniqua defensione perdurat; necatores enim pauperum iudicandi sunt, qui eorum taliter alimenta subtraxerint. Sacerdotalis tamen debet esse prouisio, ut uindictam admonitio manifesta praecedat, ut res usurpatas iniuste quis tulerit adhibeta aequitate restituat. Quod si neglexerit et necessitas compulerit, postea praedonem sacerdotalis districtio maturata percellat".

${ }^{36} \mathrm{Na}$ znaczenie tego ustalenia zwróciła uwagę B.H. Rosenwein (Negotiating Space, s. 44-45).

${ }^{37}$ Por. Concilium Turonense (567), can. 25 (24), CCL 148A, 192: „Qui si pertinaciter in peruasione persteterit et se tollere post tertiam communicionem de reicola aut ecclesiae aut propria noluerit, conueniant omnis omnino una coniuentia simul cum nostris abbatibus ac presbyteris uel clero, qui stipendiis ex ipso alimento pascuntur, et, quia arma nobis non sunt altera, auxiliante Christo circumsepto clericali choro necaturi pauperum, qui res peruadit ecclesiae, psalmos CVIII dicatur, ut ueniat super eum illa maledictio, quae super Iudam uenit, qui, dum loculos faceret, subtrahebat pauperum alimenta".

${ }^{38}$ Por. tamże: ,ut non solum excommunis, sed etiam anathema moriatur et coelesti gladio feriatur, qui in dispectu dei et ecclesiae et pontificum in hac peruersionem praesumit assurgere".

${ }^{39}$ Por. tamże: ,Illud etiam annecti placuit, ut, qui de fratribus ad dandum solatium uenire pro certa infirmitatis necessitate non potuerit, abbates et presbyteros in uice sua transmittat. Qui si preter certam infirmitatis excusationem commonitus aut uenire aut transmittere noluerit, remotum se a fratrum caritate esse cognoscat. Nam, quod quidem non credimus, si quis contra decreta nostra tali 
Przeprowadzona analiza tekstów synodalnych prowadzi do kilku dalszych, ogólnych wniosków i refleksji.

W prawodawstwie synodów galijskich, jakie miały miejsce do końca działalności synodalnej w okresie Merowingów, a więc praktycznie do końca VII w. znajduje się kilkanaście tekstów, w których użyte jest wyrażenie „zabójca potrzebujących” (necator egentium) albo „zabójca ubogich” (necator pauperum) na określenie winnych różnych form naruszenia własności kościelnej, dóbr instytucji dobroczynnych albo własności duchownych.

Wyrażenie to zasadniczo dotyczy dwóch rodzajów nadużyć. Pierwszym z nich jest zatrzymanie ofiar należnych Kościołowi, w tym szczególnie ofiar złożonych lub przepisanych testamentem przez osoby zmarłe, albo próby odebrania ofiar już złożonych. W okresie merowińskim zmienia się sytuacja Kościoła i pojawia się także nowy rodzaj przestępstwa - różne formy zaboru albo pomniejszenia dóbr kościelnych.

W obu wypadkach - choć nie we wszystkich tekstach synodalnych - pojawiają się uzasadnienia takiego określenia oparte na stwierdzeniu, że z pieniędzy ofiarowanych Kościołowi utrzymywani są ludzie biedni i potrzebujący. W większości wypadków synody określają też surową karę, jaka wiązała się z uznaniem winnego za zabójcę ubogich albo potrzebujących: wykluczenie ze wspólnoty Kościoła, ekskomunika, pozbawienie komunii. Brak uzasadnień i określenia kary w niektórych tekstach oznacza najprawdopodobniej, że idea necator pauperum i związane z nią sankcje karne były wystarczająco znane i nie wymagały wyjaśnień.

W poszukiwaniu odpowiedzi na pytanie o intencje jakie przyświecały synodom uchwalającym przeanalizowane teksty trzeba wziąć pod uwagę szeroko zakrojone dzieło charytatywne Kościoła galijskiego ${ }^{40}$, które wymagało wielkich nakładów materialnych, stąd przypominanie o należnych Kościołowi ofiarach. Kiedy także w okresie Merowingów majątki Kościoła się rozrastają i stają się celem różnych ataków, pojawia się potrzeba ich ochrony. Trudno jednoznacznie stwierdzić jakie były najistotniejsze motywacje biskupów i czy troska o biednych nie ustępowała niekiedy trosce o nienaruszalność kościelnej kasy $^{41}$, ale na pewno dbałość o materialną bazę Kościoła była silna.

Przeprowadzone studium ukazuje Kościół galijski w świetle szczególnego źródła historycznego jakim są teksty synodalne, bardzo czułe na aktualną sytuację i będące odpowiedzią na bardzo konkretne i realne zagrożenia zewnętrzne

temeratori communicare praesumpserit, in se causam excommunicationis transformet et cum eodem se a caritate omnium sacerdotum cognoscat esse remotum".

${ }^{40}$ Por. Skibiński, Dzieło charytatywne Kościoła w Galii w IV-VII wieku, s. 379-391.

${ }^{41}$ Jest to widoczne także w ustaleniach synodalnych innych regionów, por. G. Ryś, Majątek kościelny w starożytnym prawodawstwie synodalnym, w: Studia i rozprawy ofiarowane profesorowi Tytusowi Górskiemu, red. S. Stabryła - R.M. Zawadzki, Kraków 2003, 223. 
i wewnętrzne. Pozwala spojrzeć na ten Kościół w okresie intensywnych przemian politycznych, społecznych i kulturowych, szukający swojego miejsca w nowym po-rzymskim świecie, w czasach nowych szans i nowych zagrożeń. Przedstawia wąski wycinek kościelnej rzeczywistości, ale bardzo interesujący i charakterystyczny dla Kościoła galijskiego w kontekście stojących przed nim wyzwań, zagrażających mu niebezpieczeństw i przyświecających ideałów.

\section{NECATOR PAUPERUM AND NECATOR EGENTIUM \\ IN THE LEGISLATION OF GALLIC SYNODS FROM THE $5^{\mathrm{TH}}$ TO THE $7^{\mathrm{TH}}$ CENTURIES}

(Summary)

One of the characteristic concepts present in the documents of the Gallic synods from the $5^{\text {th }}$ to the $7^{\text {th }}$ centuries is necator pauperum (slayer of the poor), and related to it necator egentium (slayer of the needy). This article aims to analyse the use of these expressions in the synodal legislation. It shows that the notion generally refers to two types of abuse: retention of the offers due to the Church, and various forms of seizure of Church property. The synods also stipulate severe penalties against those judged guilty of being "slayers of the poor". The study presents the Gallic Church during a very intense political, social and cultural transition. It is a Church looking for its place in the new post-roman world, at a time of new opportunities and new dangers.

Key words: Gaul, synods, necator pauperum, necator egentium.

Slowa kluczowe: Galia, synody, necator pauperum, necator egentium.

\section{BIBLIOGRAFIA}

\section{Źródła}

Concilium Agathense (506), Prologi et canones, ŹMT 73 [wyd. łacińsko-polskie, układ i opracowanie A. Baron - H. Pietras], tłum. B. Tabor, SCL 8, Kraków 2014, 1-22.

Concilium Arelatense (554), Prologus et canones, ed. C. De Clercq, CCL 148A, Turnholti $1963,171-173$.

Concilium Aurelianense (511), Canones, ŹMT 73 [wyd. łacińsko-polskie, układ i opracowanie A. Baron - H. Pietras], tłum. A. Caba, SCL 8, Kraków 2014, 23-31.

Concilium Aurelianense (549), Canones, ŹMT 73 [wyd. łacińsko-polskie, układ i opracowanie A. Baron - H. Pietras], tłum. P. Wałach, SCL 8, Kraków 2014, 315-322.

Concilium Cabilonense (647-653), Canones, ed. C. De Clercq, CCL 148A, Turnholti $1963,302-310$.

Concilium Clippiacense (626-627), Canones, ed. C. De Clercq, CCL 148A, Turnholti 1963, 291-297.

Concilium Matisconense (585), Canones, ed. C. De Clercq, CCL 148A, Turnholti 1963, 238-250. 
Concilium Parisiense (556-573), Canones, ed. C. De Clercq, CCL 148A, Turnholti 1963, 204-217.

Concilium Parisiense (614), Canones, ed. C. De Clercq, CCL 148A, Turnholti 1963, 274-285.

Concilium Turonense (567), Canones, ed. C. De Clercq, CCL 148A, Turnholti 1963, 179-194.

Concilium Valentinum (583-585), Acta, ed. C. De Clercq, CCL 148A, Turnholti 1963, 234-236.

Concilium Vasense (442), Canones, ŹMT 62 [wyd. łacińsko-polskie, układ i opracowanie A. Baron - H. Pietras], tłum. A. Caba, SCL 6, Kraków 2011, 21-24.

Hieronymus, Epistuale 1-70, ed I. Hilberg, CSEL 54, Vindobonae - Lipsiae 1910.

Statuta Ecclesiae Antiqua, ŹMT 62 [wyd. łacińsko-polskie, układ i opracowanie A. Baron - H. Pietras], tłum. A. Caba, SCL 6, Kraków 2011, 261-273.

\section{Opracowania}

FABER G., Merowingowie i Karolingowie, thum. Z. Jaworski, Warszawa 1994.

Gaudemet J. - Basdevant B., Concile de Paris III, w: Les canons des conciles Mérovingiens (VI ${ }^{-}-V I I^{e}$ siècles), t. 2, ed. J. Gaudemet - B. Basdevant, SCh 354, Paris 1989, 410-411.

HaLfond G.I., Archaeology of Frankish Church Councils, AD 511-768, Leiden - Boston 2010.

Knowles M.D. - Obolensky D., Historia Kościoła, t. 2, 600-1500, tłum. R. Turzyński, Warszawa 1988.

Moore M. E., The Ancient Fathers: Christian Antiquity, Patristics and Frankish Canon Law, „Millennium, Jahrbuch zu Kultur und Geschichte des ersten Jahrtausends n. Chr." 7 (2010) 293-342.

Munier CH., Statuta Ecclesiae Antiqua, NDPAC III 5113-5115.

Pontal O., Histoire des conciles mérovingiens, Paris 1989.

Rosenwein B.H., Negotiating Space: Power, Restraint, and Privileges of Immunity in Early Medieval Europe, Ithaca (NY) 1991.

RYś G., Majątek kościelny w starożytnym prawodawstwie synodalnym, w: Studia i rozprawy ofiarowane profesorowi Tytusowi Górskiemu, red. S. Stabryła - R.M. Zawadzki, Kraków 2003, 219-227.

SkIBIŃski T., Dzieło charytatywne Kościoła w Galii w IV-VII wieku w świetle prawodawstwa synodalnego. Zarys problematyki, VoxP 35 (2015) t. 64, 379-391.

Wood I., Królestwa Merowingów 450-751. Władza - społeczeństwo - kultura, tłum. M. Wilk, Warszawa 2012. 